\section{Kidney \\ Blood Pressure Research}

Kidney Blood Press Res 2017;42:483-494

DOI: $10.1159 / 000479640$

Published onlıne: August 04, 2017

Accepted: April 19, 2017

This article is licensed under the Creative Commons Attribution-NonCommercial-NoDerivatives 4.0 International License (CC BY-NC-ND) (http://www.kargercom/Services/OpenAccessLicense). Usage and distribution for commercial purposes as well as any distribution of modified material requires written permission.

Review

\title{
Two Liters a Day Keep the Doctor Away? Considerations on the Pathophysiology of Suboptimal Fluid Intake in the Common Population
}

\author{
Florian Lang ${ }^{a} \quad$ Isabelle Guelinckx ${ }^{b} \quad$ Guillaume Lemetais $^{b} \quad$ Olle Melander $^{c}$

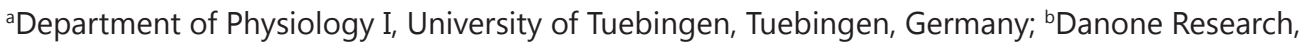 \\ Palaiseau, France; 'Department of Clinical Sciences, Lund University, Malmö, Sweden
}

\section{Key Words}

Copeptin • Glucocorticoids • Vasopressin • Metabolic syndrome • Cancer • Chronic kidney disease

\begin{abstract}
Suboptimal fluid intake may require enhanced release of antidiuretic hormone (ADH) or vasopressin for the maintenance of adequate hydration. Enhanced copeptin levels (reflecting enhanced vasopressin levels) in $25 \%$ of the common population are associated with enhanced risk of metabolic syndrome with abdominal obesity, type 2 diabetes, hypertension, coronary artery disease, heart failure, vascular dementia, cognitive impairment, microalbuminuria, chronic kidney disease, inflammatory bowel disease, cancer, and premature mortality. Vasopressin stimulates the release of glucocorticoids which in turn up-regulate the serum-and glucocorticoid-inducible kinase 1 (SGK1). Moreover, dehydration upregulates the transcription factor NFAT5, which in turn stimulates SGK1 expression. SGK1 is activated by insulin, growth factors and oxidative stress via phosphatidylinositide-3-kinase, 3-phosphoinositidedependent kinase PDK1 and mTOR. SGK1 is a powerful stimulator of $\mathrm{Na}^{+} / \mathrm{K}^{+}$-ATPase, carriers (e.g. the $\mathrm{Na}^{+}, \mathrm{K}^{+}, 2 \mathrm{Cl}^{-}$cotransporter NKCC, the $\mathrm{NaCl}$ cotransporter $\mathrm{NCC}$, the $\mathrm{Na}^{+} / \mathrm{H}^{+}$exchanger $\mathrm{NHE} 3$, and the $\mathrm{Na}^{+}$coupled glucose transporter SGLT1), and ion channels (e.g. the epithelial $\mathrm{Na}^{+}$channel $\mathrm{ENaC}$, the $\mathrm{Ca}^{2+}$ release activated $\mathrm{Ca}^{2+}$ channel Orail with its stimulator STIM1, and diverse $\mathrm{K}^{+}$channels). SGK1 further participates in the regulation of the transcription factors nuclear factor kappa-B NFKB, p53, cAMP responsive element binding protein (CREB), activator protein-1, and forkhead transcription factor FKHR-L1 (FOXO3a). Enhanced SGK1 activity fosters the development of hypertension, obesity, diabetes, thrombosis, stroke, inflammation including inflammatory bowel disease and autoimmune disease, cardiac fibrosis, proteinuria, renal failure as well as tumor growth. The present brief review makes the case that suboptimal fluid intake in the common population may enhance vasopressin and glucocorticoid levels thus up-regulating SGK1 expression and favouring the development of SGK1 related pathologies.
\end{abstract}




\section{Kidney Blood Pressure Research}

\section{Introduction}

Fine tuning of water balance is an obvious prerequisite for maintenance of cell and blood volume constancy [1]. Decrease of cell volume or of atrial distension triggers thirst and release of vasopressin, a hormone rapidly curtailing renal water excretion [1]. Vasopressin further stimulates vascular smooth muscle contraction thus preventing blood pressure drop during volume depletion [2]. Vasopressin usually prevents significant alterations of cell and blood volume at low water intake [1]. Thus, low water intake had not been considered a major health hazard. Recent observations, however, provided evidence that enhanced vasopressin plasma levels are associated with a large number of clinical disorders. Suboptimal fluid intake leading to enhanced vasopressin release may affect a large portion of the common population, as some $9 \%$ of the world wide adult population drink less than half and as many as $40 \%$ of adults between 50 and $100 \%$ of the fluid intake recommended by the European Food Safety Agency [3]

The present brief review discusses the possibility that those clinical disorders could result from a stimulating effect of vasopressin on adrenocorticotropic hormone with subsequent increase of glucocorticoid release [4,5] and up-regulation of the serum and glucocorticoid inducible kinase SGK1 [6, 7].

\section{Impact of drinking behaviour on the vasopressin-cortisol-SGK1 axis}

Total water intake (sum of water from food moisture and fluids) varies considerably in the common population $[8,9]$. The impact of low daily water intake on long term health has, in the past, attracted little attention [10]. A recent study revealed, however, that plasma vasopressin $(\mathrm{ADH})$ levels were significantly enhanced in low drinkers $(\leq 1.2$ litres/d of total fluid intake, i.e. sum of drinking water and any other fluids) as compared to high drinkers (2-4 litres/d) [8, 11]. Vasopressin is a known powerful stimulator of glucocorticoid release $[4,5]$ and low drinkers had indeed significantly higher plasma cortisol levels [8]. The pleotropic effects of glucocorticoids include upregulation of the serum- and glucocorticoidinducible kinase 1 (SGK1) $[6,7,12]$, an ubiquitously expressed kinase up-regulated during dehydration $[13,14]$. Moreover, water deprivation may up-regulate the transcription factor NFAT5 [15], which in turn stimulates the expression of SGK1 [16]. Whatever underlying mechanism, severe water deprivation is followed by marked increase of SGK1 expression at least in the brain $[13,14]$. To the best of our knowledge, data showing up-regulation of SGK1 expression following suboptimal fluid intake in humans are lacking. It is conceivable, however, that the enhanced vasopressin levels in low drinkers are associated with a subtile but relevant increase of SGK1 expression resulting in the respective influence on SGK1 sensitive functions (Figure 1).

\section{Association of vasopressin (copeptin) levels with risk and outcome of diseases}

Increased plasma vasopressin levels are reflected by a similar increase of the surrogate marker copeptin, a protein released in parallel to vasopressin but more stable than vasopressin and thus reflecting the integrated hydration status more reliably [17]. Individuals with copeptin levels in the top $25 \%$ of the general population were shown to have markedly increased risk of developing type 2 diabetes independently of known diabetes risk factors [18], a finding subsequently replicated in different populations $[19,20]$. Along those lines, genetic variance of the vasopressin receptor AVPR1B is associated with overweight and diabetes $[17,21]$. Rats with high vasopressin levels had higher fasting glucose levels than rats with low vasopressin levels [22]. In obese rats, high vasopressin levels lead to hyperinsulinaemia, glucose intolerance, and insulin insensitivity, whereas an arginine vasopressin receptor 


\section{Kidney \\ Blood Pressure Research}

Fig. 1. Putative mechanisms linking suboptimal water intake and SGK1 dependent pathophysiology $(\mathrm{ADH}=$ antidiuretic hormone $=$ vasopressin; ACTH = adrenocorticotropic hormone; SGK1 = serum \& glucocorticoid inducible kinase 1 ; CKD = chronic kidney disease; $\mathrm{CHD}=$ Chronic heart disease; IBD = inflammatory bowel disease).

1A (V1aR) antagonist reduced glucose intolerance [22]. Obese rats with low vasopressin were protected against liver steatosis, hepatic triacylglycerol and cholesterol accumulation and expression of hepatic lipogenic genes [22]. Elevated copeptin is not only associated with increased risk of type 2 diabetes but with the entire cluster of metabolic syndrome $[23,24]$ especially with abdominal obesity [23, $25,26]$. Copeptin predicts not only diabetes but its main complications such as coronary artery disease and individuals with high levels of copeptin actually die earlier than people with normal values of copeptin $[24,27]$.

Interestingly, high copeptin is also associated with a broad range of other diseases such as heart failure [28], vascular dementia [27], cognitive impairment [29], microalbuminuria [25], chronic kidney disease [17, 30], inflammatory bowel disease [31], cancer [32], and premature mortality [24].

\section{SGK1-sensitive cellular functions}

SGK1 is a powerful stimulator of $\mathrm{Na}^{+} / \mathrm{K}^{+}$-ATPase, of diverse carriers (e.g. $\mathrm{Na}^{+}, \mathrm{K}^{+}, 2 \mathrm{Cl}^{-}$ cotransporter NKCC, $\mathrm{NaCl}$ cotransporter NCC, $\mathrm{Na}^{+} / \mathrm{H}^{+}$exchanger NHE3, and $\mathrm{Na}^{+}$coupled glucose transporter SGLT1), and ion channels (e.g. epithelial $\mathrm{Na}^{+}$channel ENaC, the $\mathrm{Ca}^{2+}$ release activated $\mathrm{Ca}^{2+}$ channel Orai1 with its stimulator STIM1, the neuronal kainate receptor, and diverse $\mathrm{K}^{+}$channels) [33-35]. SGK1 further participates in the regulation of the transcription factors nuclear factor kappa-B NFKB, p53, cAMP responsive element binding protein (CREB), activator protein-1 (AP-1), and forkhead transcription factor FKHR-L1 (FOXO3a) [33]. SGK1 participates in the orchestration of a wide variety of complex cellular functions including 


\section{Kidney Blood Pressure Research}

organization of the cytoskeleton [36], cell volume regulation [37], cell survival and cell proliferation [7, 38, 39], cell migration [40,41], degranulation [36, 42], hormone release $[37,43]$, renal tubular $\mathrm{Na}^{+}$reabsorption [37, 43-46], renal tubular $\mathrm{K}^{+}$transport [47], gastric acid secretion [7, 37], as well as intestinal $\mathrm{Na}^{+}$and nutrient transport [43]. SGK1 may affect neuronal excitability [48], but the potential pathophysiological role of SGK1 in the brain remained hitherto elusive.

\section{Impact of SGK1 on renal transport and hypertension}

SGK1 stimulates the $\mathrm{Na}^{+}, \mathrm{K}^{+}, 2 \mathrm{Cl}^{-}$cotransporter NKCC [43], the $\mathrm{NaCl}$ cotransporter NCC $[7,37,45,49,50]$, the $\mathrm{Na}^{+} / \mathrm{H}^{+}$exchanger NHE3 [37, 51-55] and the epithelial $\mathrm{Na}^{+}$channel $\mathrm{ENaC}$ [7] and thus augments renal tubular salt reabsorption [7, 37, 44, 46, 56]. Moreover, SGK1 stimulates salt appetite and thus salt intake [7, 43, 57]. Increased SGK1 activity thus predisposes to extracellular volume expansion and hypertension [50, 56, 58-61]. Along those lines, several SGK1 gene variants are associated with increased blood pressure [60] including combined polymorphisms in intron 6 [I6CC] and exon 8 [E8CC/CT] [37, 43, 62]. The [I6CC/E8CC/CT] gene polymorphism is more common in Africans (10\%) than in Caucasians $(3-5 \%)[37,43]$. Blood pressure is normal in gene targeted mice lacking SGK1 $\left(\mathrm{sg} \mathrm{k1}^{\circ}\right)$ at regular diet [43], but, in contrast to blood pressure of wild-type littermates, does not increase following induction of hyperinsulinism with high-fructose diet or high-fat diet $[43,63]$. Apparently, hyperinsulinism leads to hypertension through SGK1-sensitive mechanisms such as stimulation of renal tubular salt reabsorption [37, 43]. Along those lines, SGK1 contributes to glucocorticoid-induced hypertension [37]. Furthermore, maternal SGK1 may be critically important for fetal programming of hypertension. SGK1 is expressed in the endometrium [64] and maternal SGK1 is required for the hypertension in the offspring following protein restriction during pregnancy [65].

\section{Impact of SGK1 on intestinal transport and obesity}

SGK1 stimulates the intestinal $\mathrm{Na}^{+}$coupled glucose transporter SGLT1 $[37,66]$. Enhanced activity of the carrier fosters the development of obesity, an effect presumably due to acceleration of postprandial increase of plasma glucose concentration, which is followed by excessive insulin release and subsequent fat deposition [37, 43]. SGK1 up-regulates SGLT1 and may thus support the development of obesity $[37,43]$. SGK1 further supports adipocyte differentiation and adipogenesis [67]. Along those lines, the I6CC/E8CC/CT SGK1 gene variant is associated with increased body weight and enhanced risk to develop diabetes [37]. In diabetic individuals hyperglycemia may in turn stimulate intestinal SGK1 expression $[37,43]$ with subsequent up-regulation of intestinal SGLT1 activity thus supporting further weight gain.

\section{SGK1 sensitive $\mathrm{Ca}^{2+}$ channel activity and platelet function}

By stimulating the transcription factor nuclear factor kappa B (NFkB), SGK1 up-regulates the expression of the $\mathrm{Ca}^{2+}$ channel Orai1 and of its stimulator, the $\mathrm{Ca}^{2+}$ sensing protein STIM1, which accomplish the store operated $\mathrm{Ca}^{2+}$ entry (SOCE) [7, 37, 68-70]. Upon store depletion SOCE leads to an increase of cytosolic $\mathrm{Ca}^{2+}$ concentration, a key event in the stimulation of blood platelets. SGK1-sensitive upregulation of the platelet $\mathrm{Ca}^{2+}$ channel Orai1/STIM1 enhances the sensitivity of blood platelets to stimulators leading to enhanced degranulation and aggregation [68]. Moreover, SGK1 stimulates coagulation by stimulating tissue factor expression [37]. Up-regulation of SGK1 thus predisposes to thrombosis [68] and stroke [59, 71]. 


\section{Kidney Blood Pressure Research}

\section{Role of SGK1 in tumor growth}

Strong SGK1 expression was observed in diverse tumors [39] including non-small cell lung cancer [72], colon cancer [39], prostate cancer [73], ovarian tumors [7], myeloma [74], and medulloblastoma [7]. Intriguing evidence suggests that SGK1 may confer survival of tumor cells $[7,43,75,76]$, such as interleukin 6 (IL6)-induced survival of cholangiocarcinoma cells [39, 43], interleukin 2 (IL2)-dependent survival of kidney cancer cells [7], angiotensin II-induced survival of fibrosarcoma-derived cells [77], and androgen receptor-dependent survival of prostate cancer cells [7]. SGK1 silencing overcomes resistance of breast cancer cells to chemotherapy $[39,43,78]$, and pharmacological SGK1 inhibition blunts androgeninduced growth of prostate cancer cells [37]. SGK1 further attenuates the proapoptotic effect of membrane androgen receptors (mAR) [7] in colon carcinoma cells [40, 79]. SGK1 knockout counteracts the development of spontaneous tumors in APC deficient mice [37] and chemically induced colonic tumours in wild-type mice [7]. Parallel inhibition of SGK1 may enhance the efficacy of treatment with cytotoxic drugs or radiation [80].

SGK1 influences cell proliferation and cell death by up-regulating channels and transporters, such as the store operated $\mathrm{Ca}^{2+}$ entry (SOCE) accomplished by Orai1/STIM1 [7, $68,69,80-82]$. SOCE maintains oscillations of cytosolic $\mathrm{Ca}^{2+}$ activity, which are required for depolymerization of the actin filament network, a prerequisite for cell proliferation $[39,43]$. $\mathrm{Ca}^{2+}$ entry is driven by the cell membrane potential, which is generated by SGK1 sensitive $\mathrm{K}^{+}$ channels $[39,43]$.

SGK1 is further in part effective by inactivation of the proapoptotic forkhead transcription factor Foxo3a/ FKRHL1 [7], inhibition of glycogen synthase kinase GSK-3 with subsequent up-regulation of oncogenic $ß$-catenin [43, 75], activation of $\operatorname{IKK} \beta$, with subsequent phosphorylation and degradation of the inhibitory protein I $\mathrm{B}$ and translocation of NFKB into the nucleus [39], activation of the ubiquitin ligase MDM2 with subsequent MDM2dependent ubiquitination and proteosomal degradation of proapoptotic transcription factor p53 [7], interference with SEK1 binding to JNK1 and MEKK1 [39, 43], as well as upregulation of Ran binding protein (RanBP), which in turn modifies the microtubule network and decreases taxol sensitivity of cancer cells [83].

SGK1 stimulates cellular glucose uptake, a prerequisite of the excessive glycolytic flux due to aerobic glycolysis in tumor cells [43]. SGK1 further stimulates the $\mathrm{Na}^{+} / \mathrm{H}^{+}$ion exchanger [70], which generates an alkaline cytosolic $\mathrm{pH}$ thus enhancing glycolytic flux [7]. SGK1 is up-regulated by ischemia, which renders tumor cells particularly dependent on glycolysis [37, 39, 43, 84].

Low SGK1 abundance has been found in some types of prostate cancer, ovarian tumors, hepatocellular carcinoma and adenomatous polyposis coli (APC) [7, 39, 43]. A positive correlation was observed between SGK1 abundance and patient survival in adrenocortical carcinoma [85, 86]. Possibly, tumor cells with high activity of related kinases such as PKB/ Akt isoforms or SGK3 downregulate SGK1 and do not require SGK1 for growth and survival.

\section{SGK1 sensitive inflammation and fibrosis}

SGK1 contributes to the orchestration of inflammation [33] including inflammatory bowel disease [87, 88]. The kinase is required for inactivation of the transcription factor Foxo1, which stimulates expression of the IL23 receptor [89] and is thus required for the stimulating effect of interleukin 23 (IL-23) on the generation of interleukin (IL)-17-producing $\mathrm{CD}^{+}$helper $\mathrm{T}$ cells ( $\mathrm{T}_{\mathrm{H}} 17$ cells) [90]. $\mathrm{T}_{\mathrm{H}} 17$ cells upregulate the pro-inflammatory cytokines GM-CSF, TNF- $\alpha$ and IL-2 and play a pivotal role in autoimmune disease [90]. Up-regulation of SGK1 thus presumably predisposes to a particularly severe form of experimental autoimmune encephalomyelitis with enhanced infiltration of $\mathrm{T}_{\mathrm{H}} 17$ cells into the central nervous system [90]. 


\section{Kidney Blood Pressure Research}

Table 1. Comparison of clinical conditions correlated with enhanced copeptin levels and the respective disorders shown or expected following SGK1 excess. Among the clinical conditions associated with high copeptin levels only cognitive impairment $[27,29]$ may be related to mechanisms other than increased SGK1 expression. The other clinical disordes are presumably at least in part due to enhanced SGK1 expression and activity. This does, however, not rule out the involvement of further mechanisms and additional experimental effort is needed to define the pathophysiological role of SGK1 in individuals with suboptimal fluid intake.

\begin{tabular}{llll}
\hline $\begin{array}{l}\text { Enhanced Copeptin levels are } \\
\text { associated with }\end{array}$ & References & $\begin{array}{l}\text { Enhanced SGK1 activity } \\
\text { may contribute to }\end{array}$ & References \\
\hline Hypertension & {$[23,24]$} & Hypertension & {$[37,43,50,56,58-63]$} \\
Obesity & {$[23-26]$} & Obesity & {$[37,43]$} \\
Type 2 diabetes & {$[18-20]$} & Type 2 diabetes & {$[37]$} \\
Coronary artery disease vascular dementia & {$[24,27]$} & Atherosclerosis, stroke & {$[59,68,71,107-109]$} \\
Heart failure & {$[28]$} & Cardiac remodeling/fibrosis & {$[7,103-106,110]$} \\
Microalbuminuria & {$[25]$} & Proteinuria & {$[101,111]$} \\
Chronic kidney disease & {$[17,30]$} & Renal fibrosis & {$[101]$} \\
Inflammatory bowel disease & {$[31]$} & Inflammatory bowel disease & {$[87,88]$} \\
Cancer & {$[32]$} & Cancer & {$[7,37,39,40,43,72-80]$} \\
\hline
\end{tabular}

SGK1 further participates in the orchestration of tissue fibrosis. Excessive SGK1 expression was observed in lung fibrosis, diabetic nephropathy, glomerulonephritis, experimental nephrotic syndrome, obstructive nephropathy, liver cirrhosis, fibrosing pancreatitis, peritoneal fibrosis, Crohn's disease and coeliac disease [7, 43, 91, 92]. SGK1 expression is up-regulated by TGF $\beta$ [43], a key stimulator of fibrosis [88, 93-98]. TGFß is in part effective through transcription factors Smad2/3 [7], which are degraded by the ubiquitin ligase Nedd4L [7]. SGK1 inactivates Nedd4L and thus augments the effects of TGFß [7]. SGK1 activates NFKB [43], a transcription factor fostering inflammation and fibrosis [7, $99,100]$. NFKB regulated proteins include connective tissue growth factor (CTGF), which contributes to cardiac fibrosis [43], renal proteinuria and failure [101], as well as skin aging [102] following mineralocorticoid excess. SGK1 is further involved in angiotensin IIinduced cardiac CTGF formation and fibrosis $[103,104]$, in cardiac remodelling following increased afterload $[7,105,106]$ and in augmentation of fibronectin formation at excessive extracellular glucose concentrations [7].

\section{Conclusions}

Compelling evidence suggests that suboptimal fluid intake is followed by pathophysiologically relevant release of vasopressin, which in turn may foster the development of several clinical disorders including metabolic syndrome, abdominal obesity, type 2 diabetes, hypertension, coronary artery disease, heart failure, vascular dementia, cognitive impairment, microalbuminuria, chronic kidney disease, inflammatory bowel disease, cancer, and premature mortality (table 1). At least in theory, vasopressin could be effective by stimulating the release of adrenocorticotropic hormone with subsequent glucocorticoid release and enhanced expression of serum and glucocorticoid inducible kinase SGK1. Alternatively, dehydration could stimulate SGK1 through upregulation of the transcription factor NFAT5/TonEBP. Similar to suboptimal water intake SGK1 has been shown to participate in the pathophysiology of hypertension, obesity, diabetes, thrombosis, stroke, cardiac failure, proteinuria, renal failure, inflammatory bowel disease, and tumor growth (table 1). Additional experimental effort is needed to explore whether SGK1 contributes to cognitive impairment during suboptimal water intake, and whether suboptimal water intake is associated with further SGK1 sensitive pathologies such as autoimmune disease, allergy and excessive gastric acid secretion. Moreover, more rigorous experimental evidence 


\section{Kidney Bloód Pressure Research}

is required defining the potential contribution of SGK1 to the pathophysiology following suboptimal water intake. Whatever mechanisms involved, optimal water intake may prevent, delay or attenuate those severe potentially life threatening clinical disorders.

\section{Disclosure Statement}

The authors of this manuscript state that they do not have any conflict of interests and nothing to disclose.

\section{Acknowledgements}

The authors acknowledge the meticulous preparation of manuscript and figure by Lejla Subasic and Tanja Loch.

\section{References}

1 Danziger J, Zeidel ML: Osmotic homeostasis. Clin J Am Soc Nephrol 2015;10:852-862.

2 Treschan TA, Peters J: The vasopressin system: physiology and clinical strategies. Anesthesiology 2006;105:599-612; quiz 639-540.

-3 Ferreira-Pego C, Guelinckx I, Moreno LA, Kavouras SA, Gandy J, Martinez H, Bardosono S, Abdollahi M, Nasseri E, Jarosz A, Babio N, Salas-Salvado J: Total fluid intake and its determinants: cross-sectional surveys among adults in 13 countries worldwide. Eur J Nutr 2015;54:S35-43.

4 Holsboer F, Ising M: Stress hormone regulation: biological role and translation into therapy. Annu Rev Psychol 2010;61:81-109, C101-111.

5 Papadimitriou A, Priftis KN: Regulation of the hypothalamic-pituitary-adrenal axis. Neuroimmunomodulation 2009;16:265-271.

-6 Firestone GL, Giampaolo JR, O'Keeffe BA: Stimulus-dependent regulation of serum and glucocorticoid inducible protein kinase (SGK) transcription, subcellular localization and enzymatic activity. Cell Physiol Biochem 2003;13:1-12.

7 Lang F, Stournaras C: Serum and glucocorticoid inducible kinase, metabolic syndrome, inflammation, and tumor growth. Hormones (Athens) 2013;12:160-171.

-8 Perrier E, Vergne S, Klein A, Poupin M, Rondeau P, Le Bellego L, Armstrong LE, Lang F, Stookey J, Tack I: Hydration biomarkers in free-living adults with different levels of habitual fluid consumption. Br J Nutr 2013;109:1678-1687.

-9 Iglesia I, Guelinckx I, De Miguel-Etayo PM, Gonzalez-Gil EM, Salas-Salvado J, Kavouras SA, Gandy J, Martinez H, Bardosono S, Abdollahi M, Nasseri E, Jarosz A, Ma G, Carmuega E, Thiebaut I, Moreno LA: Total fluid intake of children and adolescents: cross-sectional surveys in 13 countries worldwide. Eur J Nutr 2015;54:S57-67.

10 Guelinckx I, Vecchio M, Perrier ET, Lemetais G: Fluid Intake and Vasopressin: Connecting the Dots. Ann Nutr Metab 2016;68:S6-11.

11 Johnson EC, Munoz CX, Jimenez L, Le Bellego L, Kupchak BR, Kraemer WJ, Casa DJ, Maresh CM, Armstrong LE: Hormonal and Thirst Modulated Maintenance of Fluid Balance in Young Women with Different Levels of Habitual Fluid Consumption. Nutrients 2016;8:pii: E302.

$>12$ Yun CC, Chen Y, Lang F: Glucocorticoid activation of $\mathrm{Na}(+) / \mathrm{H}(+)$ exchanger isoform 3 revisited. The roles of SGK1 and NHERF2. J Biol Chem 2002;277:7676-7683.

13 Bohmer C, Philippin M, Rajamanickam J, Mack A, Broer S, Palmada M, Lang F: Stimulation of the EAAT4 glutamate transporter by SGK protein kinase isoforms and PKB. Biochem Biophys Res Commun 2004;324:1242-1248. 


\section{Kidney \\ Blood Pressure Research}

14 Warntges S, Friedrich B, Henke G, Duranton C, Lang PA, Waldegger S, Meyermann R, Kuhl D, Speckmann EJ, Obermuller N, Witzgall R, Mack AF, Wagner HJ, Wagner A, Broer S, Lang F: Cerebral localization and regulation of the cell volume-sensitive serum- and glucocorticoid-dependent kinase SGK1. Pflugers Arch 2002;443:617-624.

15 Neuhofer W: Role of NFAT5 in inflammatory disorders associated with osmotic stress. Curr Genomics 2010;11:584-590.

16 Chen S, Grigsby CL, Law CS, Ni X, Nekrep N, Olsen K, Humphreys MH, Gardner DG: Tonicity-dependent induction of Sgk1 expression has a potential role in dehydration-induced natriuresis in rodents. J Clin Invest 2009;119:1647-1658.

17 Tasevska I, Enhorning S, Christensson A, Persson M, Nilsson PM, Melander O: Increased Levels of Copeptin, a Surrogate Marker of Arginine Vasopressin, Are Associated with an Increased Risk of Chronic Kidney Disease in a General Population. Am J Nephrol 2016;44:22-28.

18 Enhorning S, Wang TJ, Nilsson PM, Almgren P, Hedblad B, Berglund G, Struck J, Morgenthaler NG, Bergmann A, Lindholm E, Groop L, Lyssenko V, Orho-Melander M, Newton-Cheh C, Melander O: Plasma copeptin and the risk of diabetes mellitus. Circulation 2010;121:2102-2108.

-19 Abbasi A, Corpeleijn E, Meijer E, Postmus D, Gansevoort RT, Gans RO, Struck J, Hillege HL, Stolk RP, Navis G, Bakker SJ: Sex differences in the association between plasma copeptin and incident type 2 diabetes: the Prevention of Renal and Vascular Endstage Disease (PREVEND) study. Diabetologia 2012;55:1963-1970.

-20 Wannamethee SG, Welsh P, Papacosta O, Lennon L, Whincup PH, Sattar N: Copeptin, Insulin Resistance, and Risk of Incident Diabetes in Older Men. J Clin Endocrinol Metab 2015;100:3332-3339.

-21 Roussel R, El Boustany R, Bouby N, Potier L, Fumeron F, Mohammedi K, Balkau B, Tichet J, Bankir L, Marre M, Velho G: Plasma Copeptin, AVP Gene Variants, and Incidence of Type 2 Diabetes in a Cohort From the Community. J Clin Endocrinol Metab 2016;101:2432-2439.

-22 Taveau C, Chollet C, Waeckel L, Desposito D, Bichet DG, Arthus MF, Magnan C, Philippe E, Paradis V, Foufelle F, Hainault I, Enhorning S, Velho G, Roussel R, Bankir L, Melander O, Bouby N: Vasopressin and hydration play a major role in the development of glucose intolerance and hepatic steatosis in obese rats. Diabetologia 2015;58:1081-1090.

-23 Enhorning S, Struck J, Wirfalt E, Hedblad B, Morgenthaler NG, Melander O: Plasma copeptin, a unifying factor behind the metabolic syndrome. J Clin Endocrinol Metab 2011;96:E1065-1072.

-24 Melander 0: Vasopressin, from Regulator to Disease Predictor for Diabetes and Cardiometabolic Risk. Ann Nutr Metab 2016;68:S24-28.

-25 Enhorning S, Bankir L, Bouby N, Struck J, Hedblad B, Persson M, Morgenthaler NG, Nilsson PM, Melander O: Copeptin, a marker of vasopressin, in abdominal obesity, diabetes and microalbuminuria: the prospective Malmo Diet and Cancer Study cardiovascular cohort. Int J Obes (Lond) 2013;37:598-603.

-26 Saleem U, Khaleghi M, Morgenthaler NG, Bergmann A, Struck J, Mosley TH, Jr., Kullo IJ: Plasma carboxyterminal provasopressin (copeptin): a novel marker of insulin resistance and metabolic syndrome. J Clin Endocrinol Metab 2009;94:2558-2564.

-27 Tasevska I, Enhorning S, Persson M, Nilsson PM, Melander O: Copeptin predicts coronary artery disease cardiovascular and total mortality. Heart 2016;102:127-132.

28 Enhorning S, Hedblad B, Nilsson PM, Engstrom G, Melander O: Copeptin is an independent predictor of diabetic heart disease and death. Am Heart J 2015;169:549-556, e541.

-29 Tufvesson E, Melander O, Minthon L, Persson M, Nilsson PM, Struck J, Nagga K: Diabetes mellitus and elevated copeptin levels in middle age predict low cognitive speed after long-term follow-up. Dement Geriatr Cogn Disord 2013;35:67-76.

-30 Pikkemaat M, Melander O, Bengtsson Bostrom K: Association between copeptin and declining glomerular filtration rate in people with newly diagnosed diabetes. The Skaraborg Diabetes Register. J Diabetes Complications 2015;29:1062-1065.

-31 Ohlsson B, Melander O: Basal Plasma Levels of Copeptin are Elevated in Inactive Inflammatory Bowel Disease after Bowel Resection. Drug Target Insights 2015;9:21-27.

-32 Belting M, Almgren P, Manjer J, Hedblad B, Struck J, Wang TJ, Bergmann A, Melander O: Vasoactive peptides with angiogenesis-regulating activity predict cancer risk in males. Cancer Epidemiol Biomarkers Prev 2012;21:513-522.

-33 Lang F, Stournaras C, Alesutan I: Regulation of transport across cell membranes by the serum- and glucocorticoid-inducible kinase SGK1. Mol Membr Biol 2014;31:29-36. 


\section{Kidney \\ Blood Pressure Research}

-34 Matschke V, Theiss C, Hollmann M, Schulze-Bahr E, Lang F, Seebohm G, Strutz-Seebohm N: NDRG2 phosphorylation provides negative feedback for SGK1-dependent regulation of a kainate receptor in astrocytes. Front Cell Neurosci 2015;9:387.

-35 Strutz-Seebohm N, Seebohm G, Shumilina E, Mack AF, Wagner HJ, Lampert A, Grahammer F, Henke G, Just L, Skutella T, Hollmann M, Lang F: Glucocorticoid adrenal steroids and glucocorticoid-inducible kinase isoforms in the regulation of GluR6 expression. J Physiol 2005;565:391-401.

36 Schmid E, Gu S, Yang W, Munzer P, Schaller M, Lang F, Stournaras C, Shumilina E: Serum- and glucocorticoid-inducible kinase SGK1 regulates reorganization of actin cytoskeleton in mast cells upon degranulation. Am J Physiol Cell Physiol 2013;304:C49-C55.

37 Lang F, Gorlach A, Vallon V: Targeting SGK1 in diabetes. Expert Opin Ther Targets 2009;13:1303-1311.

38 Chen L, Wei TQ Wang Y, Zhang J, Li H, Wang KJ: Simulated bladder pressure stimulates human bladder smooth muscle cell proliferation via the PI3K/SGK1 signaling pathway. J Urol 2012;188:661-667.

39 Lang F, Perrotti N, Stournaras C: Colorectal carcinoma cells--regulation of survival and growth by SGK1. Int J Biochem Cell Biol 2010;42:1571-1575.

40 Schmidt EM, Gu S, Anagnostopoulou V, Alevizopoulos K, Foller M, Lang F, Stournaras C: Serum- and glucocorticoid-dependent kinase-1-induced cell migration is dependent on vinculin and regulated by the membrane androgen receptor. FEBS J 2012;279:1231-1242.

-41 Schmidt EM, Kraemer BF, Borst O, Munzer P, Schonberger T, Schmidt C, Leibrock C, Towhid ST, Seizer P, Kuhl D, Stournaras C, Lindemann S, Gawaz M, Lang F: SGK1 sensitivity of platelet migration. Cell Physiol Biochem 2012;30:259-268.

-42 Hua SZ: Mapped! A machinery of degranulation in mast cells. Focus on "Serum- and glucocorticoidinducible kinase SGK1 regulates reorganization of actin cytoskeleton in mast cells upon degranulation". Am J Physiol Cell Physiol 2013;304:C36-C37.

43 Lang F, Bohmer C, Palmada M, Seebohm G, Strutz-Seebohm N, Vallon V: (Patho)physiological significance of the serum- and glucocorticoid-inducible kinase isoforms. Physiol Rev 2006;86:1151-1178.

44 Faresse N, Lagnaz D, Debonneville A, Ismailji A, Maillard M, Fejes-Toth G, Naray-Fejes-Toth A, Staub 0: Inducible kidney-specific Sgk1 knockout mice show a salt-losing phenotype. Am J Physiol Renal Physiol 2012;302:F977-F985.

45 Rotin D, Staub 0: Nedd4-2 and the regulation of epithelial sodium transport. Front Physiol 2012;3:212.

46 Soundararajan R, Lu M, Pearce D: Organization of the ENaC-regulatory machinery. Crit Rev Biochem Mol Biol 2012;47:349-359.

47 Lang F, Vallon V: Serum- and glucocorticoid-inducible kinase 1 in the regulation of renal and extrarenal potassium transport. Clin Exp Nephrol 2012;16:73-80.

48 Lang F, Strutz-Seebohm N, Seebohm G, Lang UE: Significance of SGK1 in the regulation of neuronal function. J Physiol 2010;588:3349-3354.

-49 Arroyo JP, Lagnaz D, Ronzaud C, Vazquez N, Ko BS, Moddes L, Ruffieux-Daidie D, Hausel P, Koesters R, Yang B, Stokes JB, Hoover RS, Gamba G, Staub O: Nedd4-2 modulates renal Na+-Cl- cotransporter via the aldosterone-SGK1-Nedd4-2 pathway. J Am Soc Nephrol 2011;22:1707-1719.

50 Pao AC: SGK regulation of renal sodium transport. Curr Opin Nephrol Hypertens 2012;21:534-540.

-51 Dynia DW, Steinmetz AG, Kocinsky HS: NHE3 function and phosphorylation are regulated by a calyculin A-sensitive phosphatase. Am J Physiol Renal Physiol 2010;298:F745-F753.

52 He P, Lee SJ, Lin S, Seidler U, Lang F, Fejes-Toth G, Naray-Fejes-Toth A, Yun CC: Serum- and glucocorticoidinduced kinase 3 in recycling endosomes mediates acute activation of $\mathrm{Na}+\mathrm{H}+$ exchanger NHE3 by glucocorticoids. Mol Biol Cell 2011;22:3812-3825.

53 Panchapakesan U, Pollock C, Saad S: Renal epidermal growth factor receptor: its role in sodium and water homeostasis in diabetic nephropathy. Clin Exp Pharmacol Physiol 2011;38:84-88.

54 Pao AC, Bhargava A, Di Sole F, Quigley R, Shao X, Wang J, Thomas S, Zhang J, Shi M, Funder JW, Moe OW, Pearce D: Expression and role of serum and glucocorticoid-regulated kinase 2 in the regulation of $\mathrm{Na}+\mathrm{H}+$ exchanger 3 in the mammalian kidney. Am J Physiol Renal Physiol 2010;299:F1496-F1506.

55 Pasham V, Rotte A, Gu S, Yang W, Bhandaru M, Rexhepaj R, Pathare G, Lang F: Upregulation of Intestinal NHE3 Following Saline Ingestion. Kidney Blood Press Res 2013;37:48-57.

-56 Resch M, Bergler T, Fredersdorf S, Griese DP, Weil J, Kreuzer P, Brunner S, Riegger GA, Luchner A, Endemann DH: Hyperaldosteronism and altered expression of an SGK1-dependent sodium transporter in ZDF rats leads to salt dependence of blood pressure. Hypertens Res 2010;33:1082-1088. 


\section{Kidney \\ Blood Pressure Research}

57 Umbach AT, Pathare G, Foller M, Brosens JJ, Artunc F, Lang F: SGK1-dependent salt appetite in pregnant mice. Acta Physiol (Oxf) 2011;202:39-45.

-58 Kawarazaki H, Ando K, Shibata S, Muraoka K, Fujita M, Kawarasaki C, Fujita T: Mineralocorticoid receptor-Rac1 activation and oxidative stress play major roles in salt-induced hypertension and kidney injury in prepubertal rats. J Hypertens 2012;30:1977-1985.

-59 Nakagaki T, Hirooka Y, Matsukawa R, Nishihara M, Nakano M, Ito K, Hoka S, Sunagawa K: Activation of mineralocorticoid receptors in the rostral ventrolateral medulla is involved in hypertensive mechanisms in stroke-prone spontaneously hypertensive rats. Hypertens Res 2012;35:470-476.

60 Rao AD, Sun B, Saxena A, Hopkins PN, Jeunemaitre X, Brown NJ, Adler GK, Williams JS: Polymorphisms in the serum- and glucocorticoid-inducible kinase 1 gene are associated with blood pressure and renin response to dietary salt intake. J Hum Hypertens 2013;27:176-180.

61 Nakano M, Hirooka Y, Matsukawa R, Ito K, Sunagawa K: Mineralocorticoid receptors/epithelial $\mathrm{Na(+)}$ channels in the choroid plexus are involved in hypertensive mechanisms in stroke-prone spontaneously hypertensive rats. Hypertens Res 2013;36:277-284.

-62 von Wowern F, Berglund G, Carlson J, Mansson H, Hedblad B, Melander O: Genetic variance of SGK-1 is associated with blood pressure, blood pressure change over time and strength of the insulin-diastolic blood pressure relationship. Kidney Int 2005;68:2164-2172.

-63 Ackermann TF, Boini KM, Beier N, Scholz W, Fuchss T, Lang F: EMD638683, a novel SGK inhibitor with antihypertensive potency. Cell Physiol Biochem 2011;28:137-146.

64 Salker MS, Christian M, Steel JH, Nautiyal J, Lavery S, Trew G, Webster Z, Al-Sabbagh M, Puchchakayala G, Foller M, Landles C, Sharkey AM, Quenby S, Aplin JD, Regan L, Lang F, Brosens JJ: Deregulation of the serum- and glucocorticoid-inducible kinase SGK1 in the endometrium causes reproductive failure. Nat Med 2011;17:1509-1513.

65 Rexhepaj R, Boini KM, Huang DY, Amann K, Artunc F, Wang K, Brosens JJ, Kuhl D, Lang F: Role of maternal glucocorticoid inducible kinase SGK1 in fetal programming of blood pressure in response to prenatal diet. Am J Physiol Regul Integr Comp Physiol 2008;294:R2008-2013.

66 Rexhepaj R, Alesutan I, Gu S, Pelzl L, Eichenmuller M, Pathare G, Foller M, Kuhl D, Lang F: SGK1-dependent stimulation of intestinal SGLT1 activity by vitamin D. Pflugers Arch 2011;462:489-494.

67 Di Pietro N, Panel V, Hayes S, Bagattin A, Meruvu S, Pandolfi A, Hugendubler L, Fejes-Toth G, Naray-FejesToth A, Mueller E: Serum- and glucocorticoid-inducible kinase 1 (SGK1) regulates adipocyte differentiation via forkhead box 01. Mol Endocrinol 2010;24:370-380.

-68 Borst O, Schmidt EM, Munzer P, Schonberger T, Towhid ST, Elvers M, Leibrock C, Schmid E, Eylenstein A, Kuhl D, May AE, Gawaz M, Lang F: The serum- and glucocorticoid-inducible kinase 1 (SGK1) influences platelet calcium signaling and function by regulation of Orai1 expression in megakaryocytes. Blood 2012;119:251-261.

69 Eylenstein A, Schmidt S, Gu S, Yang W, Schmid E, Schmidt EM, Alesutan I, Szteyn K, Regel I, Shumilina E, Lang F: Transcription factor NF-kappaB regulates expression of pore-forming Ca2+ channel unit, Orai1, and its activator, STIM1, to control Ca2+ entry and affect cellular functions. J Biol Chem 2012;287:2719-2730.

70 Rotte A, Pasham V, Eichenmuller M, Yang W, Bhandaru M, Lang F: Influence of dexamethasone on $\mathrm{Na}^{+} / \mathrm{H}^{+}$ exchanger activity in dendritic cells. Cell Physiol Biochem 2011;28:305-314.

71 Dahlberg J, Smith G, Norrving B, Nilsson P, Hedblad B, Engstrom G, Lovkvist H, Carlson J, Lindgren A, Melander 0: Genetic variants in serum and glucocortocoid regulated kinase 1, a regulator of the epithelial sodium channel, are associated with ischaemic stroke. J Hypertens 2011;29:884-889.

72 Abbruzzese C, Mattarocci S, Pizzuti L, Mileo AM, Visca P, Antoniani B, Alessandrini G, Facciolo F, Amato R, D'Antona L, Rinaldi M, Felsani A, Perrotti N, Paggi MG: Determination of SGK1 mRNA in non-small cell lung cancer samples underlines high expression in squamous cell carcinomas. J Exp Clin Cancer Res 2012;31:4.

73 Szmulewitz RZ, Chung E, Al Ahmadie H, Daniel S, Kocherginsky M, Razmaria A, Zagaja GP, Brendler CB, Stadler WM, Conzen SD: Serum/glucocorticoid-regulated kinase 1 expression in primary human prostate cancers. Prostate 2012;72:157-164.

74 Fagerli UM, Ullrich K, Stuhmer T, Holien T, Kochert K, Holt RU, Bruland O, Chatterjee M, Nogai H, Lenz G, Shaughnessy JD, Jr., Mathas S, Sundan A, Bargou RC, Dorken B, Borset M, Janz M: Serum/glucocorticoidregulated kinase 1 (SGK1) is a prominent target gene of the transcriptional response to cytokines in multiple myeloma and supports the growth of myeloma cells. Oncogene 2011;30:3198-3206. 


\section{Kidney \\ Blood Pressure Research}

75 Lang F, Artunc F, Vallon V: The physiological impact of the serum and glucocorticoid-inducible kinase SGK1. Curr Opin Nephrol Hypertens 2009;18:439-448.

-76 Towhid ST, Liu GL, Ackermann TF, Beier N, Scholz W, Fuchss T, Toulany M, Rodemann HP, Lang F: Inhibition of Colonic Tumor Growth by the Selective SGK Inhibitor EMD638683. Cell Physiol Biochem 2013;32:838848.

-77 Baskin R, Sayeski PP: Angiotensin II mediates cell survival through upregulation and activation of the serum and glucocorticoid inducible kinase 1. Cell Signal 2012;24:435-442.

-78 Sommer EM, Dry H, Cross D, Guichard S, Davies BR, Alessi DR: Elevated SGK1 predicts resistance of breast cancer cells to Akt inhibitors. Biochem J 2013;452:499-508.

79 Gu S, Papadopoulou N, Nasir O, Foller M, Alevizopoulos K, Lang F, Stournaras C: Activation of membrane androgen receptors in colon cancer inhibits the prosurvival signals Akt/bad in vitro and in vivo and blocks migration via vinculin/actin signaling. Mol Med 2011;17:48-58.

-80 Lang F, Voelkl J: Therapeutic potential of serum and glucocorticoid inducible kinase inhibition. Expert Opin Investig Drugs 2013;22:701-714.

-81 Eylenstein A, Gehring EM, Heise N, Shumilina E, Schmidt S, Szteyn K, Munzer P, Nurbaeva MK, Eichenmuller M, Tyan L, Regel I, Foller M, Kuhl D, Soboloff J, Penner R, Lang F: Stimulation of Ca2+-channel Orai1/STIM1 by serum- and glucocorticoid-inducible kinase 1 (SGK1). FASEB J 2011;25:2012-2021.

82 Schmidt S, Schneider S, Yang W, Liu G, Schmidt EM, Schmid E, Mia S, Brucker S, Stournaras C, Wallwiener D, Brosens JJ, Lang F: TGFbeta1 and SGK1-sensitive store-operated Ca2+ entry and Orai1 expression in endometrial Ishikawa cells. Mol Hum Reprod 2014;20:139-147.

-83 Amato R, Scumaci D, D'Antona L, Iuliano R, Menniti M, Di Sanzo M, Faniello MC, Colao E, Malatesta P, Zingone A, Agosti V, Costanzo FS, Mileo AM, Paggi MG, Lang F, Cuda G, Lavia P, Perrotti N: Sgk1 enhances RANBP1 transcript levels and decreases taxol sensitivity in RKO colon carcinoma cells. Oncogene 2013;32:4572-4578.

84 Rusai K, Prokai A, Szebeni B, Fekete A, Treszl A, Vannay A, Muller V, Reusz G, Heemann U, Lutz J, Tulassay T, Szabo AJ: Role of serum and glucocorticoid-regulated kinase-1 in the protective effects of erythropoietin during renal ischemia/reperfusion injury. Biochem Pharmacol 2010;79:1173-1181.

85 Ronchi CL, Leich E, Sbiera S, Weismann D, Rosenwald A, Allolio B, Fassnacht M: Single nucleotide polymorphism microarray analysis in cortisol-secreting adrenocortical adenomas identifies new candidate genes and pathways. Neoplasia 2012;14:206-218.

-86 Ronchi CL, Sbiera S, Leich E, Tissier F, Steinhauer S, Deutschbein T, Fassnacht M, Allolio B: Low SGK1 Expression in Human Adrenocortical Tumors Is Associated with ACTH-Independent Glucocorticoid Secretion and Poor Prognosis. J Clin Endocrinol Metab 2012;97:E2251-E2260.

-87 Waldegger S, Klingel K, Barth P, Sauter M, Rfer ML, Kandolf R, Lang F: H-SGK serine-threonine protein kinase gene as transcriptional target of transforming growth factor beta in human intestine. Gastroenterology 1999;116:1081-1088.

-88 Szebeni B, Vannay A, Sziksz E, Prokai A, Cseh A, Veres G, Dezsofi A, Gyorffy H, Szabo IR, Arato A: Increased expression of serum- and glucocorticoid-regulated kinase- 1 in the duodenal mucosa of children with coeliac disease. J Pediatr Gastroenterol Nutr 2010;50:147-153.

-89 Wu C, Yosef N, Thalhamer T, Zhu C, Xiao S, Kishi Y, Regev A, Kuchroo VK: Induction of pathogenic T17 cells by inducible salt-sensing kinase SGK1. Nature 2013;496:513-517.

-90 Kleinewietfeld M, Manzel A, Titze J, Kvakan H, Yosef N, Linker RA, Muller DN, Hafler DA: Sodium chloride drives autoimmune disease by the induction of pathogenic T17 cells. Nature 2013;496:518-522.

-91 Cheng J, Truong LD, Wu X, Kuhl D, Lang F, Du J: Serum- and glucocorticoid-regulated kinase 1 is upregulated following unilateral ureteral obstruction causing epithelial-mesenchymal transition. Kidney Int 2010;78:668-678.

$\$ 92$ Akhurst RJ, Hata A: Targeting the TGFbeta signalling pathway in disease. Nat Rev Drug Discov 2012;11:790-811.

-93 Hong Y, Cao H, Wang Q, Ye J, Sui L, Feng J, Cai X, Song H, Zhang X, Chen X: MiR-22 may Suppress Fibrogenesis by Targeting TGFbetaR I in Cardiac Fibroblasts. Cell Physiol Biochem 2016;40:1345-1353.

\$4 Guo Y, Dong Z, Shi Y, Wang W, Wang L, Sun J, Sun X, Tian Z, Yao J, Li Z, Cheng J, Tian Y: Sonodynamic Therapy Inhibits Fibrogenesis in Rat Cardiac Fibroblasts Induced by TGF-beta1. Cell Physiol Biochem 2016;40:579588. 


\section{Kidney \\ Blood Pressure Research}

-95 Yu F, Yang J, Huang K, Pan X, Chen B, Dong P, Zheng J: The Epigenetically-Regulated microRNA-378a Targets TGF-beta2 in TGF-beta1-Treated Hepatic Stellate Cells. Cell Physiol Biochem 2016;40:183-194.

-96 Li X, Han D, Tian Z, Gao B, Fan M, Li C, Li X, Wang Y, Ma S, Cao F: Activation of Cannabinoid Receptor Type II by AM1241 Ameliorates Myocardial Fibrosis via Nrf2-Mediated Inhibition of TGF-beta1/Smad3 Pathway in Myocardial Infarction Mice. Cell Physiol Biochem 2016;39:1521-1536.

-97 Zhang F, Dang Y, Li Y, Hao Q, Li R, Qi X: Cardiac Contractility Modulation Attenuate Myocardial Fibrosis by Inhibiting TGF-beta1/Smad3 Signaling Pathway in a Rabbit Model of Chronic Heart Failure. Cell Physiol Biochem 2016;39:294-302.

-98 Feger M, Alesutan I, Castor T, Mia S, Musculus K, Voelkl J, Lang F: Inhibitory effect of NH4Cl treatment on renal Tgfss1 signaling following unilateral ureteral obstruction. Cell Physiol Biochem 2015;37:955-964.

99 Shih VF, Tsui R, Caldwell A, Hoffmann A: A single NFkappaB system for both canonical and non-canonical signaling. Cell Res 2011;21:86-102.

100 Stone KP, Kastin AJ, Pan W: NFkB is an unexpected major mediator of interleukin-15 signaling in cerebral endothelia. Cell Physiol Biochem 2011;28:115-124.

101 Artunc F, Amann K, Nasir O, Friedrich B, Sandulache D, Jahovic N, Risler T, Vallon V, Wulff P, Kuhl D, Lang F: Blunted DOCA/high salt induced albuminuria and renal tubulointerstitial damage in gene-targeted mice lacking SGK1. J Mol Med (Berl) 2006;84:737-746.

102 Tsai V, Parker WE, Orlova KA, Baybis M, Chi AW, Berg BD, Birnbaum JF, Estevez J, Okochi K, Sarnat HB, Flores-Sarnat L, Aronica E, Crino PB: Fetal brain mTOR signaling activation in tuberous sclerosis complex. Cereb Cortex 2014;24:315-327.

103 Chilukoti RK, Mostertz J, Bukowska A, Aderkast C, Felix SB, Busch M, Volker U, Goette A, Wolke C, Homuth G, Lendeckel U: Effects of irbesartan on gene expression revealed by transcriptome analysis of left atrial tissue in a porcine model of acute rapid pacing in vivo. Int J Cardiol 2013;168:2100-2108.

104 Yang M, Zheng J, Miao Y, Wang Y, Cui W, Guo J, Qiu S, Han Y, Jia L, Li H, Cheng J, Du J: Serum-glucocorticoid regulated kinase 1 regulates alternatively activated macrophage polarization contributing to angiotensin II-induced inflammation and cardiac fibrosis. Arterioscler Thromb Vasc Biol 2012;32:1675-1686.

105 Das S, Aiba T, Rosenberg M, Hessler K, Xiao C, Quintero PA, Ottaviano FG, Knight AC, Graham EL, Bostrom P, Morissette MR, Del Monte F, Begley MJ, Cantley LC, Ellinor PT, Tomaselli GF, Rosenzweig A: Pathological role of serum- and glucocorticoid-regulated kinase 1 in adverse ventricular remodeling. Circulation 2012;126:2208-2219.

106 Voelkl J, Lin Y, Alesutan I, Ahmed MS, Pasham V, Mia S, Gu S, Feger M, Saxena A, Metzler B, Kuhl D, Pichler BJ, Lang F: Sgk1 sensitivity of $\mathrm{Na}(+) / \mathrm{H}(+)$ exchanger activity and cardiac remodeling following pressure overload. Basic Res Cardiol 2012;107:236.

107 Walker-Allgaier B, Schaub M, Alesutan I, Voelkl J, Geue S, Munzer P, Rodriguez JM, Kuhl D, Lang F, Gawaz M, Borst O: SGK1 up-regulates Orai1 expression and VSMC migration during neointima formation after arterial injury. Thromb Haemost 2017;117:1002-1005.

108 Borst O, Schaub M, Walker B, Schmid E, Munzer P, Voelkl J, Alesutan I, Rodriguez JM, Vogel S, Schoenberger T, Metzger K, Rath D, Umbach A, Kuhl D, Muller, II, Seizer P, Geisler T, Gawaz M, Lang F: Pivotal role of serum- and glucocorticoid-inducible kinase 1 in vascular inflammation and atherogenesis. Arterioscler Thromb Vasc Biol 2015;35:547-557.

109 Walker B, Schmid E, Russo A, Schmidt EM, Burk O, Munzer P, Velic A, Macek B, Schaller M, Schwab M, Seabra MC, Gawaz M, Lang F, Borst O: Impact of the serum- and glucocorticoid-inducible kinase 1 on platelet dense granule biogenesis and secretion. J Thromb Haemost 2015;13:1325-1334.

110 Vallon V, Wyatt AW, Klingel K, Huang DY, Hussain A, Berchtold S, Friedrich B, Grahammer F, Belaiba RS, Gorlach A, Wulff P, Daut J, Dalton ND, Ross J, Jr., Flogel U, Schrader J, Osswald H, Kandolf R, Kuhl D, Lang F: SGK1-dependent cardiac CTGF formation and fibrosis following DOCA treatment. J Mol Med (Berl) 2006;84:396-404.

111 Artunc F, Nasir O, Amann K, Boini KM, Haring HU, Risler T, Lang F: Serum- and glucocorticoid-inducible kinase 1 in doxorubicin-induced nephrotic syndrome. Am J Physiol Renal Physiol 2008;295:F1624-1634. 